\title{
A Súmula Vinculante n. 13 e a nomeação de diretores de agências reguladoras e embaixadores
}

\author{
Binding Legal Precedent $n .13$ and the appointment of directors of regulatory \\ agencies and ambassadors
}

Giovani da Silva Corralo

Universidade de Passo Fundo

Doutor em Direito pela UFPR

Professor da graduação e do PPGDireito da UPF

Passo Fundo/RS/Brasil

gcorralo@upf.br

ID Fernanda Rotta Zanella
Universidade de Passo Fundo
Graduanda em Direito pela Universidade de Passo Fundo
Pesquisadora bolsista FAPERGS
Serafina Correia/RS/Brasil
fernandazanellaa@gmail.com

Resumo: A presente pesquisa tem por foco o estudo da aplicação da Súmula Vinculante n. 13, do Supremo Tribunal, na nomeação de diretores de agências reguladoras e embaixadores, cargos que requerem a aprovação do Senado Federal. Utiliza-se o método dedutivo e pesquisa bibliográfica e documental. Para tanto, estudam-se os princípios da moralidade, eficiência e impessoalidade, de suma importância para a limitação de práticas patrimonialistas, a exemplo do nepotismo, e a aplicação da Súmula Vinculante n. 13 pelo Supremo Tribunal Federal, nos seus mais diversos julgados. Na sequência compreendem-se os cargos de diretores de agências reguladoras e de embaixador, consoante a legislação que disciplina a matéria, o que permite configurar o caráter predominantemente administrativo nas suas atribuições, logo, sem que possam ser considerados cargos políticos que estejam fora do alcance da referida súmula. Conclui-se pela aplicação da Súmula Vinculante n. 13 para os cargos de embaixador e diretor de agências reguladoras.

Palavras-chave: diretor de agência reguladora; embaixador; nepotismo; Súmula Vinculante n. 13.

\begin{abstract}
This research focuses on the study of the application of the Binding Precedent n. 13, of the Federal Supreme Court, in the appointment of directors of regulatory agencies and ambassadors, positions that require the approval of the Federal Senate. The deductive method and bibliographical and documentary research are used. Therefore, the principles of morality, efficiency and impersonality are studied, which are extremely important for limiting patrimonial practices, such as nepotism, and the application of Binding Precedent n. 13 by the Federal Supreme Court, in its most diverse judgments. Next, the positions of directors of regulatory agencies and ambassadors are understood, according to the legislation that governs the matter, which allows for the predominantly administrative character of their attributions,
\end{abstract}


therefore, without being considered political positions that are out of reach of the aforementioned summary. It is concluded by the application of the Binding Precedent n. 13 for the positions of ambassador and director of regulatory agencies.

Keywords: ambassador; Binding Precedent n. 13; nepotismo; regulatory agency director.

\section{Para citar este artigo}

ABNT NBR 6023:2018

CORRALO, Giovani da Silva; ZANELLA, Fernanda Rotta. A Súmula Vinculante n. 13 e a nomeação de diretores de agências reguladoras e embaixadores. Prisma Jurídico, São Paulo, v. 20, n. 2, p. 275-295, jul./dez. 2021. http://doi.org/10.5585/prismaj.v20n2.18196.

\section{Introdução}

A presente pesquisa tem por objeto a aplicação da Súmula Vinculante n. 13, do Supremo Tribunal Federal, na nomeação de diretores de agências reguladoras e embaixadores. Perscrutase a abrangência da súmula em comento - no que tange a esses cargos - que requerem a aprovação do Senado da República, uma vez que o entendimento do Supremo Tribunal Federal afasta, prima facie, a sua aplicação para os cargos políticos.

A matéria é atual, seja pelo histórico patrimonialista na administração brasileira, seja pelas constantes afirmações do Presidente da República Jair Messias Bolsonaro, em 2019, para a nomeação do seu filho como embaixador nos Estados Unidos. Por mais que a pauta política tenha mudado, é crucial a compreensão da abrangência da Súmula Vinculante n. 13, mais concretamente para os cargos que requerem a aprovação do Senado Federal.

Para tanto, compreendem-se os princípios da moralidade, eficiência e impessoalidade, cruciais para a limitação de práticas patrimonialistas, como também para a efetiva aplicação da referida súmula pelo Supremo Tribunal Federal. Na sequência são pautados os cargos de diretores das agências reguladoras e de embaixador, o que permite concluir pela aplicação ou não das ratio decidendi do Supremo Tribunal Federal na aplicação da Súmula Vinculante n. 13.

O Estado brasileiro tem buscado superar o histórico patrimonialista que marcou a maior parte da sua história administrativa. É o que se pugnou com a reforma administrativa ocorrida na década de 30 do século passado, cujo marco foi a criação do DASP - Departamento Administrativo do Serviço Público, em 1938. Em sentido similar a reforma gerencial em meados da década de 90, há menos de 30 anos, que buscou superar o excesso de burocracia mediante uma administração focada em resultados. 
Observa-se o esforço institucional para evitar o locupletamento indevido da res publicae, entretanto, por mais que os instrumentos de controle se aprimorem, sempre há o risco do retorno às ações de favorecimento aos parentes e às pessoas próximas, práticas essas que marcaram profundamente a evolução da espécie humana. Nessa pesquisa utiliza-se o método dedutivo e pesquisa bibliográfica e documental.

Estudar os limites postos pela ordem jurídica à nomeação de parentes significa avançar no necessário amadurecimento institucional brasileiro, a repercutir em todos os níveis da federação e em todos os poderes da república.

\section{A moralidade administrativa, a súmula vinculante n. 13 e o combate ao nepotismo}

O Estado de Direito requer limites rígidos àqueles que exercem o poder do Estado, o que se aplica a todas as funções estatais, em todos os níveis. Há a necessidade de contenção do poder estatal, ao lado dos direitos inalienáveis das pessoas. Não é sem razão que a separação dos poderes é um dos requisitos essenciais para o surgimento e desenvolvimento do Direito Administrativo, juntamente com o Estado de Direito em si (MEDAUAR, 1992, p. 20-25). Por conseguinte, o administrador, no exercício da função administrativa, deve ter ciência que administra coisa alheia, diferentemente de um proprietário, que gere algo seu (LIMA, 1937, p. 19-21).

A Constituição Federal, que se encontra no topos hermenêutico do Direito brasileiro, contém princípios e regras que norteiam o ordenamento jurídico pátrio, seja o direito privado, seja o direito público, pois ambos se submetem a uma mesma Constituição. Por essa razão, no Direito Administrativo, há muito se fala da sua constitucionalização, operada pela Constituição de 1988 (BINENJBOJM, 2014, p. 61-68).

De toda a sorte, a tradição jurídica brasileira remete à existência de um regime jurídico de direito administrativo - a vincular a função administrativa - composto de princípios e regras, diferentemente do regime jurídico de direito privado. Como não há uma regra posta pelo parlamento para disciplinar o combate ao nepotismo, parte-se dos princípios informadores do regime jurídico de direito administrativo. Um princípio "não serve para atacar as normas; posiciona-se no sentido de dotá-las de validade, adaptando-as à realidade social e impedindo o seu ilegítimo exercício pelo administrador” (BASTOS, 1998, p. 44 -54).

Os princípios são indispensáveis para a administração pública, especialmente os previstos no artigo 37 da Constituição, não obstante muitos outros informem o regime jurídico 
de direito público. Entretanto, no estudo da Súmula Vinculante n. 13, destacam-se três: moralidade, eficiência e impessoalidade.

O princípio da moralidade na Administração pública “[...] foi alçado à dignidade de informador superior e pressuposto de validade de toda a atividade legal e administrativa" (SARAIVA FILHO, 1998, p. 129 - 132), o que demonstra sua atualidade e relevância normativa.

1. O princípio da moralidade administrativa não era novidade no direito brasileiro antes da Constituição, uma vez que a doutrina, a legislação e a jurisprudência pátrias já o aplicavam como informador do princípio da legalidade, compreendido como diretriz do combate ao desvio de poder, tanto em relação ao ato vinculado como ao ato discricionário (SARAIVA FILHO, 1998). Porém, a Constituição de 1988 conferiu maior alcance normativo a este princípio. Houve a busca por meios de combate à corrupção e à improbidade administrativa e "isto talvez ocorra pela inclusão do princípio da moralidade no caput do artigo $37^{1}$ e previsão das consequências da prática dos atos de improbidade no $§ 4^{\text {o } 2}$ do mesmo dispositivo" (DI PIETRO, 2016, p. 206). Neste sentido, afirma Irene Nohara (2016, p. 81) que a inclusão do princípio da moralidade na Constituição de 1988, além de demonstrar a busca por governos mais honestos, garante ao povo o direito de tê-los.

2. O princípio da moralidade confirma que "a conduta do agente público não se prende apenas ao texto legal, indo além deve obediência aos princípios morais e éticos" (RAMOS, 2010, p. 219-240). O administrador deve observar também pressupostos morais - cumulativamente à legalidade, pois aos atos que afrontam a moralidade, a consequência deve ser a nulidade ipso facto, ou seja, presumida (SARAIVA FILHO, 1998, p. 129-132).

Ainda sobre a moralidade, a análise sistêmica da ordem constitucional demonstra a existência de valores fundamentais que não podem ser limitados sem a devida justificação e requerem um "modo objetivo e impessoal de atuação administrativa", com procedimentos que permitam aos cidadãos defenderem os seus direitos, além de diversas regras que exprimem

\footnotetext{
${ }^{1}$ Constituição Federal: “Art. 37. A administração pública direta e indireta de qualquer dos Poderes da União, dos Estados, do Distrito Federal e dos Municípios obedecerá aos princípios de legalidade, impessoalidade, moralidade, publicidade e eficiência e, também, ao seguinte:"

${ }^{2}$ Constituição Federal, “Art. 37: (...) $\S 4^{\circ}$ Os atos de improbidade administrativa importarão a suspensão dos direitos políticos, a perda da função pública, a indisponibilidade dos bens e o ressarcimento ao erário, na forma e gradação previstas em lei, sem prejuízo da ação penal cabível.”
} 
inequívoca preocupação com a moralidade administrativa, a requerer "condutas sérias, leais, motivadas e esclarecedoras, mesmo que não previstas [...]”, a constituir a sua violação o agir "sem parâmetros objetivos e baseada na vontade individual do agente e o ato praticado sem a consideração da expectativa criada pela Administração" (ÁVILA, 2005, p.75-77).

Nesse diapasão, a atividade desempenhada pelos administradores pode levá-los a confundir o espaço público com a esfera privada, o que torna indispensável o princípio da impessoalidade (NORONHA, 2011, p. 235-262). Segundo Aldemir Berwig (2019, p. 65) tal princípio objetiva desvincular os atos administrativos de razões pessoais em prol dos interesses da coletividade.

O princípio da impessoalidade, junto aos demais, deve nortear as ações dos administradores. Embora isolado não faça frente a todos os problemas possíveis, embasa o funcionamento adequado dos entes e órgãos públicos. Por isso "o dever de impessoalidade incide inclusive no âmbito do poder discricionário quando a lei autoriza o administrador a escolher mais de um caminho para atingir a finalidade da lei” (NORONHA, 2011, p. 235 262).

A impessoalidade pode ser compreendida numa dimensão negativa e positiva. A primeira, quando proíbe ações e escolhas motivadas por razões pessoais, políticas e/ou econômicas. A dimensão positiva, por sua vez, requer o sopesamento e a análise de todos os fatores envolvidos numa decisão. Conduz, outrossim, a um agir isento, independente, neutro, transparente e objetivo (RIBEIRO, 1996, p. 297-341).

Também é crucial a compreensão do princípio da eficiência, que busca o respeito ao erário público e resultados úteis em tempo hábil aos cidadãos. Rafael Carvalho Rezende Oliveira (2020, p. 61) destaca a eficiência como meio de substituição da Administração Pública burocrática pela gerencial, a considerar medidas administrativas eficientes aquelas que resultem em maiores e melhores resultados com o uso do mínimo possível de recursos públicos.

Aldemir Berwig (2019, p. 67) destaca a eficiência como um dos deveres da administração pública e para atingi-la o administrador deve buscar perfeição e rendimento funcional, porém, com celeridade e seriedade, posicionamento praticamente idêntico ao defendido há muito tempo por Hely Lopes Meirelles (1995, p. 90) ao condensar a eficiência em perfeição, presteza e rendimento funcional. Para Irene Nohara (2020, p. 93) a eficiência obriga o agente público a atuar de modo coerente com os fins estatais e destaca que antes mesmo de ser considerada um princípio já havia a compreensão como faceta necessária em esfera de dever funcional. Em suma, a eficiência pode ser condensada nas ideias de "qualidade (ótimo possível), adequado custo-benefício, rendimento funcional, produtividade aceitável, celeridade, 
rentabilidade social, razoabilidade e ação idônea (eficaz), além, obviamente, do combate ao desperdício" (CORRALO, 2019, p. 265).

Impende ressalvar que não há um princípio único que deva orientar a aplicação do Direito, mas uma gama principiológica inafastável - que não somente rege a atividade pública, mas também a limita. Compreende-se que "a administração de qualquer dos Poderes da União, dos Estados, do Distrito Federal e dos Municípios devem obediência aos princípios, entre outros, de legalidade, impessoalidade, moralidade, publicidade e eficiência" (RAMOS, 2010, p. 219-240), a condicionar a validade dos atos praticados.

Sabe-se, porém, que alguns atos podem ferir estes princípios, dentre eles o nepotismo, bastante frequente quando os papas nomeavam sobrinhos, os chamados "nepotes" e demais parentes para cargos administrativos: "a prática de favorecimento não aparece como exclusiva dos papas, mas foi sobretudo utilizada pelo corpo cardinalício" (COSTA, 2005, p. 122). Esse hábito de favorecimentos há muito chegou ao solo brasileiro e aqui se encontra enraizado: "É o culto ao patrimonialismo que explica porque o favorecimento de parentes e afins no acesso a cargos e funções públicas foi comportamento considerado normal durante largos períodos de nossa história" (MODESTO, 2012).

Histórica e antropologicamente, se trata de um comportamento humano de tempos ancestrais. A sociabilidade é uma marca do homo sapiens que teve no parentesco e no altruísmo recíproco importantíssimas fontes de cooperação. Quanto maior o número de genes em comum, maior o altruísmo. (FUKUYAMA, 2013, p. 35). Foi a evolução humana em organizações impessoais - como o Estado - que impuseram limites a esta tendência inata do ser humano de reproduzir um comportamento que vigorou durante milhares de anos. Para Francis Fukuyama (2013, p. 42-43) quando essas instituições superiores impessoais rompem, há um retorno às formas anteriores de sociabilidade. Por isso as instituições devem estar sempre vigilantes, pois um comportamento que imperou por tanto tempo requer muito esforço para que não se repita no presente e no futuro.

Fatores complexos podem influenciar no crescimento do nepotismo, como a falta de perspectiva de futuro e a existência de crises (GJINOVCI, 2016, p. 431-432). Mesmo no ambiente privado, há estudos que mostram o quanto o nepotismo influencia negativamente nas relações de confiança nas organizações (KELES; ÖZKAN; BEZIRCI, 2011, p. 14), não obstante possa surtir efeitos positivos em determinadas circunstâncias, especialmente em situações difíceis em corporações que requeiram confiabilidade e resiliência (TYTKO; SMOKOVYCH, DOROKHINA, CHERNEZHENKO, STREMENOVSKY, 2020, p.167). Nesse diapasão, o nepotismo agrega considerável risco de corrupção no setor público e de abuso 
de autoridade (TYTKO; SMOKOVYCH, DOROKHINA, CHERNEZHENKO, STREMENOVSKY, 2020, p. 166).

No combate ao nepotismo no Brasil, destaca Fernanda Marinela (2018, p. 1094) que existem alguns marcos, como é o caso da Resolução n. 07 do CNJ/2005, que vedou o nepotismo no Poder Judiciário. Esta resolução, que já sofreu várias alterações, foi alvo da Ação Direta de Constitucionalidade $n^{\circ} 12 / 2008$, momento em que se reconheceu sua constitucionalidade. Oportuno destacar o voto da Ministra Carmen Lúcia: "Nem precisaria haver princípio expresso - quer da impessoalidade, quer da moralidade administrativa - para que se chegasse ao reconhecimento da constitucionalidade das proibições de contratação de parentes para os cargos públicos.” (BRASIL. STF, 2008). ${ }^{3}$

A Resolução n. 07/2005 do CNJ, ${ }^{4}$ cujo alcance se restringia ao Poder Judiciário, deu ensejo à Súmula Vinculante n. 13/2008 do Supremo Tribunal Federal, com o intuito de que fossem evitados atos de nepotismo em todos os poderes e em todos os níveis da federação, a preceituar:

\begin{abstract}
A nomeação de cônjuge, companheiro ou parente em linha reta, colateral ou por afinidade, até o terceiro grau, inclusive, da autoridade nomeante ou de servidor da mesma pessoa jurídica investido em cargo de direção, chefia ou assessoramento, para o exercício de cargo em comissão ou de confiança ou, ainda, de função gratificada na administração pública direta e indireta em qualquer dos poderes da União, dos Estados, do Distrito Federal e dos Municípios, compreendido o ajuste mediante designações recíprocas, viola a Constituição Federal (BRASIL. STF, 2008).
\end{abstract}

O nepotismo gera danos evidentes à administração pública, resultando em descrença da população para com as instituições e conduzindo a climas de instabilidade, mas seus efeitos não se limitam à espacialidade estatal. Perceptível que tal prática macula os princípios da igualdade, impessoalidade, moralidade e eficiência “"...] na exata medida que um grupo seleto, composto pelos parentes do administrador, tem acesso ao cargo nomeado por ele enquanto os demais, compostos por não parentes, ficam à mercê da sorte" (ARAKAKI; ORTIZ, 2011, p. 101 - 122).

A administração pública é espaço de todos e deve obediência aos parâmetros constitucionais. Aquele que conquistar seu cargo, por merecimento, terá tal oportunidade assegurada, visto que se iguala a todos os demais administrados: não é, pois, um meio de

\footnotetext{
${ }^{3}$ Ainda na ADC 12/2008 a Min. Carmen Lúcia expõe: "O traçado histórico brasileiro expõe a utilização dos espaços públicos pelos interesses privados, do que decorre, em grande parte - e que já haveria de ter sido extirpada há muito - a manutenção de atuações nepotistas no País” (STF, 2008).

${ }^{4}$ Acerca da abrangência Resolução 07 do CNJ: "Tal resolução veda a nomeação de cônjuge ou companheiro, além de parentes em linha reta ou colateral ou por afinidade até terceiro grau, com os magistrados ou cargos de direção e assessoramento, para ocupar cargo em comissão ou função gratificada, para contratação temporária. Veda ainda a contratação, com dispensa e inexigibilidade, de empresa que tenha como sócio esse parente. Finalmente veda o nepotismo cruzado com outros membros do tribunal ou magistrados. [...] hoje já foi estendida para todos os Poderes por meio da Súmula Vinculante n. 13" (MARINELA, 2018, p. 1093).
} 
impossibilitar o ingresso, mas de garantir um ingresso justo, livre de máculas, favorecimentos e desrespeito aos postulados constitucionais. ${ }^{5}$

Acerca das decisões do STF sobre o nepotismo, se sobressai o relevante voto do Ministro Marco Aurélio na Ação Direta de Inconstitucionalidade - ADI - n. 1521/RS de 2013, a ressalvar que o nepotismo está a menosprezar a competência do indicado em razão de vínculos de parentesco. ${ }^{6} \mathrm{O}$ nepotismo se configura de forma objetiva, pois basta o parentesco vedado pela Súmula Vinculante n. 13, independentemente da capacidade ou não daquele que fora indicado, para que se configure o ilícito, sem a necessidade de comprovação da influência familiar, o que se extrai da Rcl $19911 \mathrm{AgR} / \mathrm{ES}$ no STF. ${ }^{7}$

Ao lado dos cargos de provimento efetivo dependentes de concurso público, existem também os cargos em comissão, pautados por elevada discricionariedade, compreendidos como aqueles de caráter transitório, ocupados por qualquer cidadão, desde que obedecidos os critérios legais, a pressupor relação de confiança e somente viáveis para atividades de direção, chefia e assessoramento. Como são cargos de livre nomeação, é ad nutum a exoneração, ou seja, independente de motivação (MARINELA, 2018, p. 694). Também há funções de confiança, usualmente conhecidas pela designação de função gratificada, destinadas aos servidores de cargo de provimento efetivo para atividades de direção, chefia e assessoramento.

Quanto aos cargos de provimento efetivo - dependentes de concurso público - não impedem a nomeação de indivíduo devidamente aprovado quando houver parentesco entre ele e a autoridade que promoverá a nomeação (MAZZA, 2020, p. 141), o que não se aplica aos cargos em comissão e funções de confiança, pois a estes se aplica a Súmula Vinculante n. 13, que veda a nomeação de parentes - importa ressaltar que "a força jurígena da súmula vinculante é bastante similar à das leis" (MAZZA, 2020, p. 70). Neste sentido, o Supremo Tribunal Federal no RE n. 579951/RN ${ }^{8}$ de 2008 entendeu como desnecessária a edição de lei formal que proíba

5 Em 25 de novembro de 2005, o vice-presidente da Ordem dos Advogados do Brasil, Seção Paraná, Dirceu Galdino Cardin, conduziu uma palestra acerca do nepotismo em que afirmou: "Existem no Brasil 19.202 cargos dessa natureza, enquanto nos Estados Unidos são 701, na França são 450 e na Inglaterra, 120. [...] Por comando constitucional, o concurso público é a forma de combater o nepotismo, porque pressupõe a escolha de candidatos que tenham conhecimento, capacidade e mérito para exercer o cargo". (OAB-PR, 2005).

${ }^{6}$ Em seu voto, o Ministro Marco Aurélio destacou: “[...] de modo algum estou a menosprezar a capacidade desse ou daquele indicado. A ênfase é outra: cuida-se aqui de evitar facilidades óbvias, bem ao gosto das medidas profiláticas. Até porque quem merece não precisa de favores: quem faz por onde insiste, faz questão de demonstrar a que veio, num ritual típico da vaidade humana, buscando cargos elevados em entidades públicas onde parente próximo não possui influência maior" (BRASIL. STF, 2013).

${ }^{7}$ Conforme Rcl 199111 Agr / ES, julgado em 19.05.2005 e relatado pelo Min. Roberto Barroso, “[...] A análise da ocorrência ou não de nepotismo é objetiva, sendo desnecessária a comprovação de efetiva influência familiar na nomeação de ocupante de cargo ou função pública em comissão [...]" (BRASIL. STF, 2005).

${ }^{8}$ O RE 579951 / RN, julgado em 20.08.2008 e relatado pelo Min. Ricardo Lewandowski, prevê: “[...] Embora restrita ao âmbito do Judiciário, a Resolução 7/2005 do Conselho Nacional da Justiça, a prática do nepotismo nos demais Poderes é ilícita. II - A vedação do nepotismo não exige a edição de lei formal para coibir a prática. 
a prática do nepotismo, a bastar o artigo $37 \mathrm{da} \mathrm{CF}$, e, por conseguinte, a súmula em comento. Ademais, não há nepotismo "se a pessoa nomeada possui um parente no órgão, mas sem influência hierárquica sobre a nomeação". 9

Quanto à sua extensão, o STF, na Rcl n. 9284/SP, julgada em 30.09.2014, pontuou que “o enunciado da Súmula Vinculante n. 13 não pretendeu esgotar todas as possibilidades de configuração de nepotismo na Administração Pública", ${ }^{10}$ a permitir o controle judicial tópico de nomeações de parentes diante do nepotismo.

Necessária a percepção de que existem constantes e velozes mudanças fáticas e jurídicas impostas por um mundo cada vez mais globalizado, como é o exemplo dos filhos e dos pais socioafetivos, das famílias multiparentais, das homoafetivas e tantas outras. Nada disso está expressamente previsto na Súmula Vinculante n. 13 do STF, entretanto, observa-se a extensão da abrangência da súmula aos afins, a abranger, exemplificativamente, a nomeação de padrastro, enteados, cunhado, sobrinha do cônjuge, dentre outros. ${ }^{11}$

Embora a Súmula Vinculante n. 13 seja bastante completa e prolixa, foi omissa quanto aos cargos políticos, eivados de ainda maior discricionariedade e que, por vezes, maculados pelo nepotismo, acabam por ferir princípios constitucionais. A “[...] jurisprudência do STF preconiza que, ressalvada situação de fraude à lei, a nomeação de parentes para cargos públicos de natureza política não desrespeita o conteúdo normativo do enunciado da Súmula Vinculante n. 13 (STF - RE no 825.682, 10/02/2015)"(KNOPLOCK, 2018, p. 168).

Ainda sobre os cargos políticos, existem decisões do STF, como a Rcl 30725AgR/RJ ${ }^{12}$, julgada em 18.10.2019 e a Rcl 22339 AgR/SP ${ }^{13}$, julgada em 04.09.2018, estabelecendo que a nomeação de parentes para cargos políticos é de livre escolha, não incidindo a Súmula Vinculante n. 13. No mesmo sentido a Rcl 34057 AgR/PR, julgada em 28.06.2019, a Rcl 28449

III - Proibição que decorre diretamente dos princípios contidos no art. 37, caput, da Constituição Federal. IV Precedentes. V - RE conhecido e parcialmente provido para anular a nomeação do servidor, aparentado com agente político, ocupante, de cargo em comissão." (STF, 2008)

${ }^{9}$ ADI n. 524, julgada pelo STF- $2^{\mathrm{a}}$ Turma STF: Rcl 18.564. (MAZZA, 2020, p. 141).

${ }^{10}$ Semelhante entendimento se encontra na Rcl 15451 AgR/RJ, julgada em 27.02.2014 pelo STF.

${ }^{11}$ É o que consta na, Rcl 9013 PI, rel. Min. Ricardo Lewandowski, j. 21/09/2011, Dje 26/09/2011.

12 O Min. Relator Gilmar Mendes afirma que: “[...] a vedação da Súmula Vinculante 13 não alcança os agentes políticos, salvo comprovada fraude na nomeação, ou hipótese de nepotismo cruzado por designações recíprocas.”. Em voto que diverge do Min. Rel. Gilmar Mendes, compreende o Min. Edson Fachin neste mesmo agravo que "[...] a orientação que emerge dos debates da aprovação da Súmula, assim como dos precedentes que lhe deram origem, não autoriza a interpretação segundo a qual a designação de parentes para cargo de natureza política é imune ao princípio da impessoalidade. Noutras palavras, cargos políticos também estão abrangidos pela Súmula Vinculante".

${ }^{13}$ Agravo regimental em reclamação sobre a nomeação de cônjuge de Prefeita para ocupar cargo de Secretário municipal, com ausência de violação ao disposto na Súmula Vinculante n. 13. Cita como precedente a RE 579.951/RN, do Rel. Min. Ricardo Lewandowski, Dje 12.9.2008. 
AgR/SP ${ }^{14}$, julgada em 23.03.2018 e a Rcl 28024 AgR/SP AgR/SP, ${ }^{15}$ julgada em 29.05.2018, ambas do STF, porém, a ressalvar a importância de qualificação técnica mínima e de idoneidade que justifique a nomeação. Semelhante entendimento encontra-se na Rcl 28449 AgR / SP ${ }^{16}$, julgada em 23.03.2018.

Ainda no sentido de impor algumas restrições à nomeação de parentes em cargos político o STF manifestou na Rcl 26448 AgR/RJ, julgada em 20.12.2019, que "a proibição ao nepotismo decorre diretamente dos princípios da impessoalidade, da moralidade e da eficiência e é evidente que eles também incidem sobre os chamados cargos políticos”, ressaltando que "quanto mais alto o cargo, maior deve ser a exigência pela obediência incondicional à Constituição e a seus princípios". O STF está a analisar - tema 1.000 - em repercussão geral o preciso alcance da Súmula Vinculante n. 13 aos cargos políticos.

O Supremo Tribunal Federal, ao editar a súmula em comento, também abrangeu a hipótese de nepotismo cruzado, onde “[...] duas autoridades tentam burlar a súmula por meio da nomeação de seus parentes de forma recíproca" (ARAKAKI; ORTIZ, 2011, p. 101-122). Neste sentido, preceitua trecho da decisão do MS 24020 / DF ${ }^{17}$, julgado em 06.03.2012 pelo STF. Ainda, o Rcl 32589 AgR / SP ${ }^{18}$, julgado pelo STF em 29.03.2019, e o AgInt no AREsp $1019652 \mathrm{RS}^{19}$, julgado em 04.05.2017 pelo STJ.

14“Agravo regimental em reclamação. 2. Nomeação de esposa e filho do prefeito como secretários municipais. Agentes políticos. 3. Ausência de violação ao disposto na Súmula Vinculante 13. 4. Falta de qualificação técnica. Necessidade de exame das circunstâncias fáticas. Inviabilidade em sede reclamatória."

${ }^{15}$ Conforme voto do Min. Rel. Luís Roberto Barroso, “[...] o Supremo Tribunal Federal tem afastado a aplicação da Súmula Vinculante 13 a cargos públicos de natureza política, ressalvados os casos de inequívoca falta de razoabilidade, por manifesta ausência de qualificação técnica ou inidoneidade moral."

${ }^{16}$ Ementa: Agravo regimental em reclamação. 2. Nomeação de esposa e filho do prefeito como secretários municipais. Agentes políticos. 3. Ausência de violação ao disposto na Súmula Vinculante 13. 4. Falta de qualificação técnica. Necessidade de exame das circunstâncias fáticas. Inviabilidade em sede reclamatória. 5. Não cabimento da reclamação. 6. Agravo regimental a que se nega provimento.

17 “ [...] No mérito, configurada a prática de nepotismo cruzado, tendo em vista que a assessora nomeada pelo impetrante para exercer cargo em comissão no Tribunal Regional do Trabalho da $17^{\text {a }}$ Região, sediado em Vitória-ES, é nora do magistrado que nomeou a esposa do impetrante para cargo em comissão no Tribunal Regional do Trabalho da $1^{\text {a }}$ Região, sediado no Rio de Janeiro-RJ. A nomeação para o cargo de assessor do impetrante é ato formalmente lícito. Contudo, no momento em que é apurada a finalidade contrária ao interesse público, qual seja, uma troca de favores entre membros do Judiciário, o ato deve ser invalidado, por violação ao princípio da moralidade administrativa e por estar caracterizada a sua ilegalidade, por desvio de finalidade. Ordem denegada. Decisão unânime."

18 “[...] O TJ/SP assentou, no acórdão reclamado, a existência de vínculos cruzados de parentesco entre nomeados e nomeantes, bem como um período de mais de ano de exercício simultâneo dos cargos públicos pelos nomeados, sendo irrelevante o fato de as nomeações não terem sido realizadas no mesmo momento. Ademais, cumpre destacar que os nomeantes pertenciam ao mesmo partido (PSDB), sendo aliados na mesma região eleitoral. 2. Presente, portanto, a existência de ajuste de favores para burlar a regra do nepotismo, mediante reciprocidade nas nomeações ou designações, o que é expressamente vedado pela Súmula Vinculante 13." (STF, Rcl 6.880AgR, 2013).

19 “[...] 1. O acórdão recorrido consignou expressamente, com base no conjunto fático e probatório constante dos autos que, "não há falar, portanto, em ausência de dolo ou má-fé nas nomeações da esposa, filha e genro do Presidente da Câmara de Vereadores". 2. Concluiu, assim, pela ocorrência de nepotismo cruzado no caso em tela, bem como pela presença de elemento subjetivo a autorizar a subsunção da conduta à Lei ${ }^{\circ}$ 8429/92. 
Também há importante entendimento firmado pelo STF no ARE 858873 AgR/SP, julgado em 13.09.2019, a entender que não há violação da Súmula Vinculante n. 13 diante de lei que defina controle ainda mais rigoroso dos graus de parentesco, o que empodera estados e municípios a disporem de regras próprias mais rígidas sobre o assunto.

Mostra-se importante aprimorar a legislação e a jurisprudência, mas, principalmente, fazer com que aqueles que têm o poder de minimizar esta cultura de nepotismo tenham consciência dos danos que causam à administração pública e à sociedade como um todo, modificando o hábito de favores privados em serviços públicos. Deve-se visar, segundo estudos de Juarez Freitas (2009) uma administração consoante o regime jurídico de direito administrativo, e que concretize o direito fundamental à boa administração pública, o que está longe do nepotismo.

\section{Os cargos de diretor de agências reguladoras e de embaixador e a aplicação da Súmula Vinculante n. 13}

Em razão do problema posto, resta analisar se a nomeação para os cargos de diretor de agências reguladoras e de embaixador são abrangidos pela Súmula Vinculante n. 13. Para tanto, é preciso compreender a natureza desses cargos, sujeitos à aprovação do Senado da República, pois se forem cargos políticos estarão imunes. À análise do cargo de embaixador, inicialmente.

No cenário internacional, a Convenção de Viena sobre Relações Diplomáticas - 1964 apenas requer a concordância do Estado acreditado, que não precisa apresentar qualquer motivação, é o chamado agrément. ${ }^{20}$ Grande parte dos países não possuem o cargo de embaixador privativo dos integrantes da carreira diplomática, entretanto, muitas são as restrições - e ocorre em situações bastante excepcionais - para as nomeações que não sejam dos respectivos quadros. É o caso dos Estados Unidos, Argentina, França, Portugal e Itália (REZENDE; JARDIM, 2019, p. 4-6).

No Brasil, é a Lei n. 11.440/06 que dispõe do regime jurídico dos agentes do serviço exterior brasileiro, servidores essenciais para a execução da política exterior. $\mathrm{O}$ art. $1^{\mathrm{o}}$ salienta as atribuições próprias do corpo de servidores de provimento efetivo do serviço exterior, com exceção das nomeações para "cargos em comissão e para funções de chefia, incluídas as

A revisão de tais fundamentos, na via recursal eleita, é inviável, tendo em vista a incidência da Súmula 7/STJ. 3. Agravo interno não provido." (STJ, AgInt no AREsp: 1019652 RS 2016/0305535-2, 2017)

${ }^{20}$ Convenção de Viena sobre Relações Diplomáticas, Artigo 4: "1. O Estado acreditante deverá certificar-se de que a pessoa que pretende nomear como Chefe da Missão perante o Estado acreditado obteve o Agrément do referido Estado. 2. O Estado acreditado não está obrigado a dar ao Estado acreditante as razões da negação do 'agrément "." 
atribuições correspondentes, nos termos de ato do Poder Executivo." O cargo em comissão de Chefe de Missão Diplomática Permanente - Embaixador - deve recair sobre os integrantes da carreira, nos graus mais elevados - Ministro de Primeira Classe ou Ministro de Segunda Classe. Somente em caráter de exceção pode ser designado alguém de fora da carreira, desde que brasileiro nato com mais de 35 anos, de reconhecido mérito e com relevantes serviços prestados. $^{21}$ As expressões "reconhecido mérito" e "relevantes serviços" são conceitos legais indeterminados que devem ser concretizados levando-se em consideração a amplitude e complexidade da atuação diplomática. Não podem ser definidas sob a discricionariedade elástica das vontades políticas. Na exceção de não se nomear para embaixador integrante do corpo permanente, é preciso que o "reconhecido mérito" da pessoa e os "relevantes serviços" prestados ao país estejam objetivamente e inequivocadamente presentes.

Conforme visto, a Súmula Vinculante n. 13, prima facie, não se aplica aos cargos políticos, a restar o questionamento se o cargo de embaixador pode obter tal enquadramento, o que requer a compreensão dos cargos políticos em si. A Constituição Federal expressamente se refere ao exercício do governo no Poder Executivo como incumbência do Chefe do Executivo e seus auxiliares diretos, a pensar no contexto federativo, com abrangência aos ministros, secretários estaduais e municipais. ${ }^{22}$ São os agentes políticos que possuem ampla liberdade para a conformação de políticas públicas, diretamente subordinados ao Chefe do Executivo. É o caminho adotado pela doutrina administrativista amplamente majoritária. ${ }^{23}$ Segundo o Supremo Tribunal Federal (RE 7.590/PR, 2014) são cimentados "na fidúcia [...] detentores de um munus governamental decorrente da Constituição Federal, não estando seus agentes enquadrados na classificação de agentes administrativos. [...]" o que não afasta de pleno a possibilidade de nepotismo, pois "[...] deve ser analisado caso a caso, a fim de verificar eventual troca de favores ou fraude à lei”. Essas nomeações para cargos políticos, entretanto, não denotam um campo sem controle, pois é possível banir as nomeações irrazoáveis de

\footnotetext{
${ }^{21}$ Lei 11.440/06: “Art. 41. Os Chefes de Missão Diplomática Permanente serão escolhidos dentre os Ministros de Primeira Classe ou, nos termos do art. 46 desta Lei, dentre os Ministros de Segunda Classe. Parágrafo único. Excepcionalmente, poderá ser designado para exercer a função de Chefe de Missão Diplomática Permanente brasileiro nato, não pertencente aos quadros do Ministério das Relações Exteriores, maior de 35 (trinta e cinco) anos, de reconhecido mérito e com relevantes serviços prestados ao País."

22 Constituição Federal: "Art. 76. O Poder Executivo é exercido pelo Presidente da República, auxiliado pelos Ministros de Estado."

${ }^{23}$ É o exemplo de José dos Santos Carvalho Filho (2016, p. 620-621), Hely Lopes Meirelles (2017, p. 620), Marçal Justen Filho (2015, p. 890-894) e Celso Antônio Bandeira de Mello (2013, p. 251-252).
} 
parentes ou que constituam fraude à lei em razão de troca de favores, inaptidão técnica ou inidoneidade moral. ${ }^{24}$

Por mais que o cargo de embaixador esteja previsto no art. 52 da Constituição Federal, a requerer a aprovação do Senado da República, ${ }^{25}$ não se vislumbram elementos normativos na ordem constitucional, na doutrina e na jurisprudência que possam enquadrá-lo como cargo político. Ao contrário, pela própria disciplina da carreira diplomática prevista na Lei n. 11.440/06, decanta-se a predominância de atribuições técnicas e burocráticas. Os embaixadores devem observância aos ditames emanados da Secretaria-Geral das Relações Exteriores e do próprio Ministro de Estado, logo, sem maiores prerrogativas de elaboração de políticas públicas das relações exteriores e sem vinculação direta ao Chefe do Executivo, características essenciais dos cargos políticos no Poder Executivo.

Quanto às agências reguladoras, é preciso compreendê-las no direito brasileiro para se analisar os cargos das suas diretorias. Não obstante a influência do mundo anglo-saxão (SUNDFELD, 2006, p. 23), o impulso para esta feição mais reguladora do Estado brasileiro ocorre com a reforma gerencial em meados da década de 90 do século passado e pode ser compreendido num contexto de transmutação do papel do Estado. ${ }^{26}$ Ao lado da diminuição do aparato estatal e da consequente privatização de empresas pertencentes ao Estado, houve o impulso para o surgimento de instrumentos de regulação bastante autonomizados. Buscou-se criar instrumentos eminentemente técnicos que blindassem o poder político dos mais diversos lobbies e pressões.

Atualmente o Brasil possui 11 agências reguladoras na administração federal (Aneel, ANP, Anatel, Anvisa, ANS, ANA, Antaq, ANTT, Ancine, Anac, ANM) ${ }^{27}$ e os marcos legais genéricos centram-se nas leis 9.986/2000 e 13.848/19. O caráter de autarquia especial, a destoar das demais pessoas jurídicas de direito público autárquicas, está forjada na "ausência de tutela

\footnotetext{
${ }^{24}$ Decisão monocrática na Reclamação 12.478 em 03.11.2011 do Ministro Joaquim Barbosa com o afastamento da nomeação de secretário da educação irmão do prefeito pela inexistência de qualquer justificativa de natureza profissional, curricular ou técnica.

${ }^{25}$ Constituição Federal: “Art. 52. Compete privativamente ao Senado Federal: [...] IV - aprovar previamente, por voto secreto, após arguição em sessão secreta, a escolha dos chefes de missão diplomática de caráter permanente;"

26 “"...] el papel político del Estado en este nuevo modelo no es ya el de productor de bienes ni el de gestor de servicios públicos. Su principal función, em este ámbito de la economia, pasó a concentrarse tanto en la regulación del control de los servicios y actividades de interés público como a la promoción de la competencia que se opera, también, mediante regulaciones estatales"(CASSAGNE, 2006, p. 485).

27 Agência Nacional de Energia Elétrica (Aneel); Agência Nacional do Petróleo, Gás Natural e Biocombustíveis (ANP); Agência Nacional de Telecomunicações (Anatel); Agência Nacional de Vigilância Sanitária (Anvisa); Agência Nacional de Saúde Suplementar (ANS); Agência Nacional de Águas (ANA); Agência Nacional de Transportes Aquaviários (Antaq); Agência Nacional de Transportes Terrestres (ANTT); Agência Nacional do Cinema (Ancine); Agência Nacional de Aviação Civil (Anac); Agência Nacional de Mineração (ANM).
} 
ou de subordinação hierárquica, pela autonomia funcional, decisória, administrativa e financeira e pela investidura a termo de seus dirigentes e estabilidade durante os mandatos". ${ }^{28}$ Executam um verdadeiro poder regulador, delegado por lei, para a elaboração de normas vinculantes aos atores abrangidos pela regulação setorial (MEZENELLO, 2002, p.106). A gestão das agências reguladoras ocorre colegiadamente, mediante diretoria escolhida para fruir um mandato de 5 anos, sem recondução. A diretoria de cada agência possui 5 diretores (exceção da Ancine com 4 e da Antaq com 3 diretores) e a perda do mandato pode decorrer de renúncia, condenação judicial, processo administrativo disciplinar ou pela violação das vedações legais impostas.

A nomeação oriunda da presidência da república para a aprovação do Senado deve observar requisitos positivos e negativos previstos nas leis mencionadas. A análise desses requisitos mostra a busca de indicações que possuam o nível de competência requerida para a atuação setorial (reputação ilibada, notório conhecimento, experiência comprovada no setor público ou privado e formação acadêmica compatível), ${ }^{29}$ bem como a vedação de indicações com verniz fortemente político (vedação da indicação de agente político em todos os níveis e respectivos parentes/consanguíneos/afins até o terceiro grau; de quem tenha atuado em campanha eleitoral ou em estrutura decisória de partido político nos últimos 36 meses; dentre outras situações). ${ }^{30}$

Cada agência reguladora deve ter um corpo funcional apto para dar cabo da regulação setorial, seja em decisões específicas, seja para a expedição de atos normativos gerais. Aliás, a edição de atos normativos de interesse geral passa a requerer a análise do impacto regulatório, que nada mais é do que a pormenorização das razões técnicas que levam à atuação regulatória. Como se observa em vários exemplos mundo afora, as agências reguladoras e demais instituições altamente autônomas, pelo seu caráter técnico e tendencialmente tecnocrático, possuem o risco de agir com perda de legitimidade, o que também pode ter efeitos negativos na própria democracia: “[...] as últimas três décadas foram marcadas pelo papel crescente dos tribunais, agências burocráticas, bancos centrais e instituições supranacionais." (MOUNK, 2009, pos. 1650). As agências reguladoras também devem ter uma procuradoria própria e uma ouvidoria, cujo ouvidor, além de ser indicado pela presidência, deve ser aprovado pelo Senado.

As agências reguladoras gozam de ampla autonomia gerencial e técnica, ao mesmo tempo em que se encontram atreladas às políticas governamentais e aos limites das suas

\footnotetext{
${ }^{28}$ Lei $13.848 / 19$, art. $3^{\circ}$.

${ }^{29}$ Art. $5^{\circ}$ da Lei $9.986 / 2000$, alterada pela Lei $13.848 / 2019$.

${ }^{30}$ Art. $8^{\circ}$-A da Lei 9.986/2000, alterada pela Lei 13.848/2019.
} 
competências, a permitir, nessas situações, a possibilidade do recurso hierárquico impróprio, posição já exarada pela Advocacia Geral da União no parecer 51/06. ${ }^{31}$ Em outras palavras, o recurso é possível nas “atividades administrativas não finalísticas” (ARAÚJO, 2008, p. 249).

Além dessa elevada autonomia para as decisões das suas competências, as diretorias das agências reguladoras devem seguir as políticas delineadas pelo Estado, logo, não integram o núcleo conformador dessas políticas, tampouco há qualquer previsão constitucional a afirmar alguma natureza política - o máximo que o art. 52, III, "f" da Constituição Federal define é a competência do Senado para aprovar titulares de cargos previsto em lei, caso em comento. Também não há uma vinculação hierárquica e direta ao Chefe do Poder Executivo, seja pela autonomia técnica consignada, seja pela vinculação ao respectivo ministério ou secretaria em nível estadual ou municipal.

Ainda neste trilhar, no Agravo Regimental na Medida Cautelar na Reclamação n. 6.650, o Ministro Ayres Britto afirmou, ao se referir genericamente a entes autárquicos, que: "o cargo de superintendente de autarquia é simplesmente administrativo, não é cargo de governo, porque não é de existência necessária, só é cargo de governo todo aquele nominado pela Constituição e, como tal, de existência necessária."

Nesses termos, quanto ao cargo de dirigente de agência reguladora - autarquia especial - tal qual ocorre para o Chefe de Missão Diplomática Permanente, a indicação da presidência deve ser aprovada pelo Senado. Trata-se de ato administrativo complexo, pois depende da conjugação da vontade de entes/órgãos distintos. Essa aquiescência senatorial, por si, não configura um cargo como político, ao contrário, pois os cargos políticos auxiliares do Chefe do Executivo são por este nomeados e exonerados com amplíssima discricionariedade. Na sua grande maioria, os cargos previstos na Constituição que requerem a aprovação do Senado - no já mencionado art. 52 - apresentam requisitos de caráter técnico, como magistrados, ministros do Tribunal de Contas da União, presidente e diretores do Banco Central, Procurador-Geral da República, dentre outros.

Impende também considerar o Decreto n. 7.203/10 que veda o nepotismo na administração federal direta e indireta e que impõem normas restritivas que se somam à Súmula

\footnotetext{
31 “II - Estão sujeitas à revisão ministerial, de ofício ou por provocação dos interessados, inclusive pela apresentação de recurso hierárquico impróprio, as decisões das agências reguladoras referentes às suas atividades administrativas ou que ultrapassem os limites de suas competências materiais definidas em lei ou regulamento, ou, ainda, violem as políticas públicas definidas para o setor regulado pela Administração direta. III Excepcionalmente, por ausente o instrumento da revisão administrativa ministerial, não pode ser provido recurso hierárquico impróprio dirigido aos Ministérios supervisores contra as decisões das agências reguladoras adotadas finalisticamente no estrito âmbito de suas competências regulatórias previstas em lei e que estejam adequadas às políticas públicas definidas para o setor." (AGU, 2006).
} 
Vinculante n. 13, como a vedação de nomeação de parentes (considerados nos termos da própria súmula) em cada órgão/ministério ou ente da administração indireta, de Ministro de Estado, autoridade administrativa máxima ou detentor de cargo de direção, chefia ou assessoramento para a nomeação em cargo em comissão, contratação emergencial temporária ou estágio sem que ocorra processo seletivo público. Expressamente dispõe que as vedações “[...] estendemse aos familiares do Presidente e do Vice-Presidente da República e, nesta hipótese, abrangem todo o Poder Executivo Federal." 32

\section{Considerações finais}

Com fulcro no desenvolvimento apresentado é possível concluir:

I - O nepotismo encontra a sua razão no desenvolvimento humano e na história administrativa brasileira, permeada por relações patrimoniais, pessoais e de parentesco. Tal cenário começa a mudar com a implantação dos pressupostos burocráticos no início do séc. XX, não obstante tenha permanecido como uma sombra permanente.

II - A reforma gerencial do final do séc. XX buscou a superação da burocracia para o gerencialismo, logo, a buscar uma administração focada em resultados, como também a diminuição do intervencionismo estatal em prol de uma administração mais reguladora. A sombra patrimonialista, porém, não se dissipou.

III - Combater o nepotismo significa concretizar fortemente os princípios informadores do regime jurídico de direito administrativo, mais especificamente a moralidade, impessoalidade e eficiência.

IV - A Súmula Vinculante n. 13 do Supremo Tribunal Federal apresenta regras a serem cumpridas em todos os poderes e em todos os níveis da federação, literalmente, como a vedação de nomeação de cônjuges/companheiros/parentes/afins até o terceiro grau em linha reta/colateral/afinidade para cargos em comissão ou função gratificada da autoridade nomeante ou de servidor em cargo de direção/chefia/assessoramento.

V - Tais regras não são exaustivas e mesmo as previstas requerem a escorreita interpretação do seu alcance. As designações recíprocas também possuem maior elasticidade, pois buscam coibir a troca de favores. É possível que a vedação de nepotismo abranja outras situações não expressas na súmula. A nomeação de parentes para cargos políticos, prima facie, não

${ }^{32}$ Decreto $7.203 / 10$, art. $3, \S 2^{\circ}$. 
encontra vedação, contudo, tem se buscado coibir nomeações irrazoáveis ou que constituam fraude à lei em razão de troca de troca de favores, inaptidão técnica ou inidoneidade moral. VI - A Súmula Vinculante n. 13 se aplica à nomeação de embaixador. Primeiro, porque tal cargo não se configura como cargo político, seja por não estar assim conformado na Constituição, seja por estar atrelado hierarquicamente à Secretaria-Geral das Relações Exteriores e ao próprio Ministro de Estado, seja por não delinear políticas públicas de Estado. Segundo, porque o regime jurídico dos agentes do serviço exterior brasileiro explicita a normalidade da indicação de servidores permanentes, no final da carreira, para estes cargos situados no ápice do serviço exterior. Situações excepcionais possibilitam a indicação de quadros de forma, desde que atentem inequivocadamente aos requisitos objetivos previstos na ordem constitucional.

VII - A Súmula Vinculante n. 13 também se aplica às nomeações de dirigentes de agências reguladoras. Tais agências possuem elevada autonomia regulatória, decorrente do seu corpo técnico, com a possibilidade de recurso hierárquico somente quando transbordar as suas competências ou não observar as políticas do Estado, vinculantes. Por conseguinte, tais entes não possuem competência para conformar políticas públicas. Também não possuem um vínculo hierárquico direto com a presidência, razão pelas quais os cargos dos seus dirigentes também não são cargos políticos.

VIII - A aprovação do Senado das indicações presidenciais para embaixador e dirigentes de agências reguladoras não os transforma em cargos políticos, até mesmo porque outros cargos que seguem estes mesmos procedimentos não possuem esta conformação presidente e diretores do Banco Central, ministros do Tribunal de Contas da União, para exemplificar.

IX - A administração federal também deve observar a normatividade do Decreto Federal 7.203/2010 com normas mais restritivas que a Súmula Vinculante n. 13, tanto para a administração direta, quanto para a administração indireta.

$\mathrm{X}$ - A Súmula Vinculante n.13 se aplica para os cargos de embaixador e de diretores de agências reguladoras, em toda a sua normatividade, juntamente com o Decreto Federal 7.203/2010, já mencionado, a abranger, obviamente, a vedação de nomeação, dentre outras, de parentes do Presidente da República. 


\section{Referências}

ADVOCACIA GERAL DA UNIÃO. Parecer AGU AC-51 n. 50000.029371/2004-83. Diário Oficial da União, Brasília, 19 jun. 2006. Disponível em: encurtador.com.br/cV149. Acesso em 02 set 2020.

ARAÚJO, Luiz Henrique Diniz. Hipóteses de cabimento de recurso hierárquico e impróprio contra decisões de agências reguladoras. Revista de Informação Legislativa, v. 45, n. 178, p. 243-250, abr./jun. 2008. Disponível em: http://www2.senado.leg.br/bdsf/handle/id/176532. Acesso em 02 set. 2020.

ÁVILA, Humberto. Teoria dos princípios: da definição à aplicação dos princípios jurídicos. 4. ed. São Paulo: Malheiros, 20005.

BASTOS, Celso Ribeiro. O princípio da moralidade no direito público. Revista de Direito Constitucional e Internacional, v. 22, p. 44-54. jan./mar. 1998.

BERWIG, Aldemir. Direito administrativo. Ijuí: Editora Unijuí, 2019. E-book. (Minha biblioteca).

BINENBOJM, Gustavo. Uma teoria do direito administrativo: direitos fundamentais, democracia e constitucionalização. 3. ed. Rio de Janeiro: Renovar, 2014.

BRASIL. Supremo Tribunal Federal. Tribunal Pleno. MS 23780, Rel. Min. Joaquim Barbosa. j. em 28. 09. 2005. DJ 03. 03. 2006; Rcl 6650MC-AgR/PR, 2008; Súmula Vinculante n. 13, 2008; Rcl 6650 MC-AgR. Rel. Min. Ellen Gracie. J. em 16.10.2008, DJ 21.11.2008; RE 579951. Rel. Min. Ricardo Lewandowski, j. em 20. 08. 2008, DJ 24. 10. 2008; RE 579951, Rel. Min. Ricardo Lewandowski, j. em 20.08.2008, DJ 24.10.2008; ADC n 12- DF, Rel. Min. Carlos Britto, Dje 18.12.2009; Rcl 9013 PI, Rel. Min. Ricardo Lewandowski, j. 21/09/2011, Dje 26/09/2011; MS 24020, Rel. Min. Joaquim Barbosa, j. em 06.03.2012, DJ 13.06.2012; ADI 1.521, Rel. Min. Ricardo Lewandowski, j. em 19.06.2013; ADI n. 1.521 RS, Rel. Min. Ricardo Lewandowski, Dje 12.08.2013; Rcl 9284, Rel. Min. Dias Toffoli, j. em 30. 09. 2014, DJ 19. 11. 2014; Rcl 15451 AgR, Rel. Min. Dias Toffoli, j. em 27. 02. 2014, DJ 03. 04. 2014; Rcl 19911 AgR, Rel. Min. Roberto Barroso, j. em 19. 05. 2015, DJ 02. 06. 2015; Rcl 23131 Agr, Rel. Min. Luiz Fux, j. em 17.03.2017, DJ 18.04.2017; Rcl 28024 AgR, Rel. Min. Roberto Barroso, j. em 29. 05. 2018, DJ 25. 06. 2018; Rcl 28449 AgR, Rel. Min. Gilmar Mendes, j. em 23. 03. 2018, DJ 09. 04. 2018; Rcl 30725 AgR, Rel. Min. Gilmar Mendes, j. em 18. 10. 2019, DJ 29. 10. 2019; Rcl 32589 AgR, Rel. Min. Alexandre de Moraes, j. em 29.03.2019, DJ 05.04.2019; ARE nº 858873 AgR, Rel. Min. Ricardo Lewandowski, j. em 13. 09. 2019, DJ 23. 09. 2019; Rcl 34057 AgR, Rel. Min. Gilmar Mendes, j. em 28. 06. 2019, DJ 06. 08. 2019; Rcl nº 22339 AgR, Rel. Min. Edson Fachin, j. em 04. 09. 2018, DJ 21. 03. 2019; Rcl 26448 AgR, Rel. Min. Edson Fachin, j. em 20.12.2019, DJ 06.02.2020. Disponível em: http://portal.stf.jus.br/. Acesso em: 15 dez. 2021.

BRASIL. Superior Tribunal de Justiça. Aresp 1019652. Segunda Turma. Relator Min. Mauro Campbell Marques. julgado em:04.05.2017. DJe: 10.05.2017. Disponível em:

http://www.stj.jus.br/sites/portalp/Inicio. Acesso em: 15 dez. 2021.

CASSAGNE, Juan Carlos. Derecho administrativo. Tomo II. 8. ed. Buenos Aires: AbeledoPerrot, 2006. 
CONSELHO NACIONAL DE JUSTIÇA. Resolução $\mathbf{N}^{\mathbf{0}} 7$ de 18/10/2005. DJ ñ 218/2005, de 14/11/2005, pág. 117.

CARVALHO FILHO, José dos Santos. Manual de direito administrativo. 30. ed. São Paulo: Atlas, 2016.

CORRALO, Giovani da Silva. Silêncio, eficiência e eficácia nas administrações municipais brasileiras. A\&C - Revista de Direito Administrativo \& Constitucional, Belo Horizonte, ano 19, n. 76, p. 253-269, abr./jun. 2019. DOI: http://dx.doi.org/10.21056/aec.v19i76.1039. Disponível em: http://www.revistaaec.com/index.php/revistaaec/article/view/1039. Acesso em: 15 dez. 2021.

COSTA, Maria Antonieta Moreira da. Nepotismo e poder na Arquidiocese de Braga (12451374). Revista Lusitana Sacra, $2^{\text {a }}$ S. 17. RLS - Tomo 017. Lisboa: Universidade Católica Portuguesa, 2005. Disponível em:

https://repositorio.ucp.pt/bitstream/10400.14/4505/1/LS_S2_17_MariaAMCosta.pdf. Acesso em: 30 jul. 2020.

DI PIETRO, Maria Sylvia Zanella. Direito administrativo. 29. ed. Rio de Janeiro: Forense, 2016.

DI PIETRO, Maria Sylvia Zanella. Transformações do Direito Administrativo. Revista de Direito da Administração Pública, v. 1, p. 185-211, jun./dez. 2016.

FREITAS, Juarez. Discricionariedade adminstrativa e o direito fundamental à boa administração pública. São Paulo: Malheiros, 2009.

FUKUYAMA, Francis. As origens da ordem política: dos tempos pré-humanos à Revolução Francesa. Rio de Janeiro: Rocco Digital, 2013. Versão kindle.

GJINOVCI, Arsim. The impact of nepotism and corruption on the economy and HR, Economic and Environmental Studies. Opole University, Opole, Vol. 16, Iss. 3, pp. 421434, 2016. Disponível em: https://www.econstor.eu/handle/10419/178926. Acesso em: 15 dez. 2021.

KELES, Hatice; ÖZKAN, Tugba; BEZIRCI, Muhammet. A Study on the effects of nepotism, favoritism and cronyism on organizational trust in the auditing process in family businesses in Turkey. Internacional Business \& Economics Research Journal, v. 10, n. 9, p. 9-16, 2011. DOI: https://doi.org/10.19030/iber.v10i9.5622. Acesso em: 15 dez. 2021.

KNOPLOCK, Gustavo Mello. Manual de direito administrativo: teoria, doutrina e jurisprudência. 11. ed. São Paulo: Editora Forense. 2018. E-book. (Minha biblioteca).

JUSTEN FILHO, Marçal. Curso de direito administrativo. 11. ed. São Paulo: Revista dos Tribunais, 2015.

LIMA, Ruy Cirne. Introdução ao estudo do direito administrativo brasileiro. Porto Alegre: Globo, 1937. 
MARINELA, Fernanda. Direito administrativo. 12. ed. São Paulo: Saraiva Educação. 2018. ePUB - Minha biblioteca.

MAZZA, Alexandre. Manual de direito administrativo. São Paulo: Saraiva Educação, 2020. E-book. (Minha biblioteca).

MEDAUAR, Odete. O direito administrativo em evolução. São Paulo: Revista dos Tribunais, 1992.

MEIRELLES, Hely Lopes. Direito administrativo brasileiro. 20. ed. São Paulo: Malheiros, 1995.

MEIRELLES, Hely Lopes. Direito municipal brasileiro. 18. ed. São Paulo: Malheiros, 2017.

MELLO, Celso Antônio Bandeira de. Curso de direito administrativo. São Paulo:

Malheiros, 2013.

MENEZELLO, Maria D’Assunção Costa. Agências reguladoras e o direito brasileiro. São Paulo: Atlas, 2002.

MODESTO, Paulo. Nepotismo em cargos político-administrativos. Revista Eletrônica de Direito do Estado (REDE), Salvador, Instituto Brasileiro de Direito Público, n. 32, outubro/novembro/dezembro de 2012.

MOUNK, Yascha. O povo contra a democracia: porque a nossa liberdade corre perigo. São Paulo: Editora Schwarcz, 2009. (versão kindle).

NOHARA, Irene Patrícia. Direito administrativo. 10. ed. São Paulo: Atlas, 2020. E-book. (Minha biblioteca).

NOHARA, Irene Patrícia. Fundamentos de direito público. São Paulo: Atlas, 2016.

NORONHA, Luana. Impessoalidade Administrativa na Jurisprudência do Supremo Tribunal Federal. Revista de Direito Constitucional e Internacional. v. 76, p. 235-262, jul./set. 2011.

OLIVEIRA, Rafael Carvalho Rezende. Curso de direito administrativo. Rio de Janeiro: Grupo GEN, 2020. E-book. (Minha biblioteca).

RAMOS, Dircêo Torrecillas. Improbidade Administrativa e Política. Revista do Instituto dos Advogados de São Paulo, v. 26, p. 219-240, jul./dez. 2010.

REZENDE, Renato Monteiro de; JARDIM, Tarciso Dal Maso. Nota informativa n. 4216/19 - Senado Federal. Disponível em: https://static.poder360.com.br/2019/08/Completo-NotaTe\%CC\%81cnica-Senado-Indicac\%CC\%A7a\%CC\%83o-do-Eduardo-Bolsonaro-comoembaixador.pdf. Acesso em: 20 ago. 2020.

RIBEIRO, Maria Teresa de Melo. O princípio da imparcialidade da administração pública. Coimbra: Almedina, 1996. 
SARAIVA FILHO, Oswaldo Othon de Pontes. O Princípio da moralidade administrativa. Revista de Direito Constitucional e Internacional, v. 22, p. 129-132., jan./mar. 1998. Disponível em: https://www2.senado.leg.br/bdsf/item/id/176497. Acesso em: 24. jun. 2020.

SUNDFELD, Carlos Ari. Introdução às Agências Reguladoras. In: SUNDFELD, Carlos Ari (coord.). Direito administrativo econômico. São Paulo: Malheiros, 2006.

VICE-PRESIDENTE DA OAB-PR FALA SOBRE NEPOTISMO DURANTE SEMINÁRIO. Site oficial OAB-PR. Curitiba. 25. nov. 2005. Seção do Paraná.

TYTKO, Anna; SMOKOVYCH, Mykhailo; DOROKHINA, Yuliia; CHERNEZHENKO, Olena; STREMENOVSKYI, Serhii. Nepotism, favoritism and cronyism as a source of conflict of interest: corruption or not?. Amazonia investiga. v. 9, n. 29, p. 163-169, 2020. DOI: http://dx.doi.org/10.34069/AI/2020.29.05.19. Disponível em:

https://amazoniainvestiga.info/index.php/amazonia/article/view/1382. Acesso em: 15 dez. 2021. 